\title{
Development risk analysis method for tsunami disaster
}

\author{
Purnawan Purnawan ${ }^{1 *}$, Vera Surtia Bachtiart $^{2}$, and Titi Kurniati $^{3}$ \\ ${ }^{1}$ Andalas University, Department of Civil Engineering, Padang, Indonesia \\ ${ }^{2}$ Andalas University, Department of Environmental Engineering, Padang, Indonesia \\ ${ }^{3}$ Andalas University, Department of Civil Engineering, Padang, Indonesia
}

\begin{abstract}
After tsunami disaster hit Aceh and Mentawai Island, Indonesia Government prepare disaster prevention plan for the areas that could be hit by tsunami disaster. Government has predicted that 19 areas could hit by tsunami disaster if big earthquake occur in that areas. Based on that condition, Regional Disaster Management Agency (BPBD) in several cities has prepared the evacuation facilities to reduce the effect of tsunami if the disaster is occurred. Although, the evacuation facilities have been built, however the risk from the impact of tsunami in that areas are still could not be measured. This paper shows the method to measure tsunami disaster risk, and method to determine the priorities handling tsunami impacts in certain area. This risk analysis method was developed based on risk analysis method developed by Federal Emergency Management Agency (FEMA). The risk of tsunami disaster is determined based on three parameters, i.e: threat of tsunami, vulnerability of people, infrastructure and agriculture, the inundation impact of tsunami. The priorities of tsunami risk handling to the affected areas are determined based on the Risk Prioritisation Index (RPI). The RPI values could be determined from the risk analysis values. The RPI values indicate the risk exposure rank in the tsunami affected areas. From analysis RPI value of each area, Government could determine the area that should be prioritising prevention to facing tsunami disaster because of the high risk level that could be occurred in that area.
\end{abstract}

\section{Introduction}

After tsunami in Aceh on 26 December 2004 and tsunami in Mentawai on 25 October 2010, government increase alertness facing tsunami disaster. It is because the impacts of massive tsunami disaster have destroyed human, infrastructure and environment [1], see Fig 1. The level of tsunami disaster impacts reveal the level of disaster preparedness and the ability local infrastructure to respond to a disaster [2]. Before both of tsunami disaster, Indonesia Government never prepare the facility to facing tsunami disaster, therefore tsunami disaster in Aceh almost destroy everything in that areas. After both tsunami disasters, Indonesia Government realize that this disaster should be handled properly, then Government include tsunami disaster in National Disaster Prevention Plan [3]. Ministry of energy and mineral resources of Indonesia have identified that 19 location could be classified as tsunami prone zone [4]. Several cities have built several evacuation facilities to prevent or reduce the impact of tsunami disaster. However, government could not determine which areas that would hit the worst impact from tsunami disaster.

Several risk analysis method have been developed to handle several types of cases [5], however limited method that could be use for analyse risk tsunami disaster.

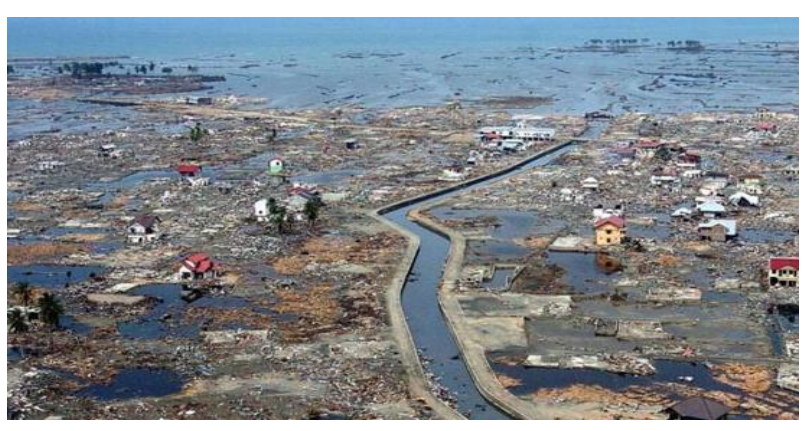

Fig 1. Impact of tsunami disaster in Aceh [1].

Risk analysis method is not possible to choose only one method to manage safety and environmental problem, joint tool or method would simplify and enhance the conditions for decision-making [5]. Based this statement and the need of tsunami risk analysis this method is developed. This paper presents a developed method to measure tsunami disaster risk in affected areas and method to determine prioritise area that to handle.

\section{The developed method}

\subsection{Risk analysis}

Development of this method adopt the process that conducted by Curtis and Carey [6], first, identify the

\footnotetext{
${ }^{*}$ Corresponding author: purnawan@ft.unand.ac.id
} 
risk, then develop assessment criteria, assess risks, assess risk interactions, risk prioritise and respond to risk.

The methods for calculating a risk modify Federal Emergency Management Agency (FEMA) method that analyse risk using variables asset value, threat and vulnerability [7] and JICA method that analyse the risk using variable vulnerability and prone rating [8]. In this study, risk analysis use variable threat, vulnerability and impact. Those variables have level that determined based on the level of conditions. The level conditions of those variables are explained in Table 1 to 6 .

\subsection{Threat level rating}

The threat of tsunami is defined as the high of tsunami inundation that could be occurred in that area. This data could be adopted from the result of tsunami disaster simulation. The depth of tsunami inundation that will swamp people and facilities for daily needs is defined as the highest threat. This depth is more than $2 \mathrm{~m}$. The different levels of threats are established based on the depth of tsunami inundation. The level of threat is shown in Table 1, then the rating of threat is shown in Table 2.

Table 1. Tsunami inundation threat.

\begin{tabular}{|c|c|c|}
\hline $\begin{array}{c}\text { Depth of } \\
\text { tsunami } \\
\text { inundation }(\mathrm{cm})\end{array}$ & $\begin{array}{c}\text { Condition caused by } \\
\text { tsunami inundation }\end{array}$ & $\begin{array}{c}\text { Level of } \\
\text { threat }\end{array}$ \\
\hline 0 & $\begin{array}{c}\text { Building floor, } \\
\text { furniture and } \\
\text { environment safe }\end{array}$ & No threat \\
\hline $0-50$ & $\begin{array}{c}\text { Private and public } \\
\text { facilities and } \\
\text { environment partially } \\
\text { submerged }\end{array}$ & Low threat \\
\hline $51-100$ & $\begin{array}{c}\text { Human, private and } \\
\text { public facilities, also } \\
\text { environment } \\
\text { submerged }\end{array}$ & Medium \\
threat \\
\hline $101-200$ & $\begin{array}{c}\text { Human, private and } \\
\text { public facilities, also } \\
\text { environment } \\
\text { submerged and } \\
\text { damaged }\end{array}$ & High threat \\
\hline 200 & $\begin{array}{c}\text { All private and public } \\
\text { facilities, also } \\
\text { environment } \\
\text { submerged and ruined }\end{array}$ & Very high \\
threat \\
\hline
\end{tabular}

Table 2. Rating of tsunami inundation threat level.

\begin{tabular}{|c|c|c|}
\hline $\begin{array}{c}\text { Depth of } \\
\text { tsunami } \\
\text { inundation }(\mathrm{cm})\end{array}$ & Level of threat & Threat rating \\
\hline 0 & Low threat & 1 \\
\hline $0-50$ & Medium threat & 3 \\
\hline $51-100$ & High threat & 4 \\
\hline $101-200$ & Very high threat & 5 \\
\hline$>200$ & \\
\hline
\end{tabular}

\subsection{Vulnerability level rating}

Vulnerability is condition that affected by physical, social, economic and environmental factors or processes which increase the susceptibility of an individual, a community, assets or systems to the impacts of hazards [9]. In this research, vulnerability is defined as the condition of target that could be hit by tsunami disaster at certain district or sub district. This condition was determined by three variables, i.e: (a) population density, (b) built infrastructure, (c) agriculture and plantation. The vulnerability rating level is shown in Table 3, 4 and 5.

Table 3. Rating of the population vulnerability level.

\begin{tabular}{|c|c|c|}
\hline $\begin{array}{c}\text { Population density } \\
\text { (population/ } \mathrm{km}^{2} \text { ) at } \\
\text { district or sub district }\end{array}$ & $\begin{array}{c}\text { Level of } \\
\text { vulnerability }\end{array}$ & $\begin{array}{c}\text { Vulnerability } \\
\text { Rating }\end{array}$ \\
\hline$<10.000$ & $\begin{array}{c}\text { Very low } \\
\text { vulnerability }\end{array}$ & 1 \\
\hline $10.000-20.000$ & $\begin{array}{c}\text { Low } \\
\text { vulnerability }\end{array}$ & 2 \\
\hline $21.000-30.000$ & $\begin{array}{c}\text { Medium } \\
\text { vulnerability }\end{array}$ & 3 \\
\hline $31.000-40.000$ & $\begin{array}{c}\text { High } \\
\text { vulnerability }\end{array}$ & 4 \\
\hline$>40.000$ & $\begin{array}{c}\text { Very high } \\
\text { vulnerability }\end{array}$ & 5 \\
\hline
\end{tabular}

Table 4. Rating of the vulnerability level of infrastructure.

\begin{tabular}{|c|c|c|}
\hline $\begin{array}{c}\text { Percentage of } \\
\text { Infrastructure area (\%) }\end{array}$ & $\begin{array}{c}\text { Level of } \\
\text { vulnerability }\end{array}$ & $\begin{array}{c}\text { Vulnerability } \\
\text { Rating }\end{array}$ \\
\hline$<10$ & $\begin{array}{c}\text { Very low } \\
\text { vulnerability }\end{array}$ & 1 \\
\hline $10-20$ & Low vulnerability & 2 \\
\hline $21-30$ & $\begin{array}{c}\text { Medium } \\
\text { vulnerability }\end{array}$ & 3 \\
\hline $31-50$ & $\begin{array}{c}\text { High } \\
\text { vulnerability } \\
\text { Very high } \\
\text { vulnerability }\end{array}$ & 4 \\
\hline
\end{tabular}

Table 5. Rating of the vulnerability level of agriculture and plantation.

\begin{tabular}{|c|c|c|}
\hline $\begin{array}{c}\text { Percentage of } \\
\text { agriculture and } \\
\text { plantation area (\%) }\end{array}$ & $\begin{array}{c}\text { Level of } \\
\text { vulnerability }\end{array}$ & $\begin{array}{c}\text { Vulnerability } \\
\text { Rating }\end{array}$ \\
\hline$<20$ & $\begin{array}{c}\text { Very low } \\
\text { vulnerability }\end{array}$ & 1 \\
\hline $21-40$ & Low vulnerability & 2 \\
\hline $41-60$ & $\begin{array}{c}\text { Medium } \\
\text { vulnerability }\end{array}$ & 3 \\
\hline $61-80$ & $\begin{array}{c}\text { High vulnerability } \\
\text { Very high } \\
\text { vulnerability }\end{array}$ & 4 \\
\hline $81-100$ & \multicolumn{2}{|c}{5} \\
\hline
\end{tabular}




\subsection{Impact level rating}

Disaster impact is the total effect, including negative effects (e.g., economic losses) and positive effects (e.g., economic gains), of a hazardous event or a disaster. The term includes economic, human and environmental impacts, and may include death, injuries, disease and other negative effects on human physical, mental and social well-being [9]. In this research, the impact is defined as the inundation area caused by tsunami disaster. This impact are measured from the percentage area of tsunami inundation compared by total area geographic administration border that determined by government, this area could be district area, sub district area and tsunami prone zone. The Rating of impact level is shown in Table 6.

Table 6. Rating of the impact level.

\begin{tabular}{|c|c|c|}
\hline $\begin{array}{c}\text { Percentage of } \\
\text { tsunami inundation } \\
\text { area (\%) }\end{array}$ & Level of impact & $\begin{array}{c}\text { Impact } \\
\text { Rating }\end{array}$ \\
\hline$<20$ & Very low impact & 1 \\
\hline $21 \%-40$ & Low impact & 2 \\
\hline $41 \%-60$ & Medium impact & 3 \\
\hline $61 \%-80$ & High impact & 4 \\
\hline $80 \%-100$ & Very high impact & 5 \\
\hline
\end{tabular}

\subsection{Risk prioritisation}

Preparation for handling tsunami disaster require prioritisation, it is because of massive and various types of impact and level of risk. Prioritisation is conducted using risk exposure values, this method modify the risk priorities method used by Sharma and Pratap [10]. Risk exposure values are calculated using equation (1), then prioritisation of areas are determined based on the risk values.

Risk $=$ Threat Rating $x$ Vulnerability Rating $x$ Impact Rating

Range of rating:

$\begin{array}{ll}\text { Threat rating } & =1-5 \\ \text { Vulnerability rating } & =1-5 \\ \text { Impact rating } & =1-5 \\ \text { Risk exposure value } & =1-125\end{array}$

Calculation of risk requires input of threat rating, vulnerability rating and impact rating, these rating could be obtained from table 1 to 6 . Then, prioritisation of risk handling could be determined based on the value of risk exposure. Prioritisation is determined using risk prioritisation index (RPI), the value of RPI is determined from table 7. This RPI indicate the rank of risk exposure in that area.
Table 7. Risk Prioritisation Index (RPI).

\begin{tabular}{|c|c|c|}
\hline $\begin{array}{c}\text { Risk exposure } \\
\text { value }\end{array}$ & Risk exposure rank & $\begin{array}{c}\text { Risk priority } \\
\text { index }\end{array}$ \\
\hline $101-125$ & Very High (VH) & 1 \\
\hline $76-100$ & $\operatorname{High}(\mathrm{H})$ & 2 \\
\hline $51-75$ & Medium (M) & 3 \\
\hline $26-50$ & Low (L) & 4 \\
\hline $1-25$ & Very Low (VL) & 5 \\
\hline
\end{tabular}

\section{Risk analysis discussions}

Tsunami risk analysis is conducted in order to classify the areas that affected by tsunami disaster. This classification is used to determine the level of priority on affected disaster areas. Based on the level of priority on this area, the government could provide disaster preparedness planning, this could include the strategy and facility that needed to handle the risk and impact of tsunami disaster. Risk analysis of tsunami disaster could be carried out using secondary data. This data include statistic data from Central Bureau of Statistic (BPS), tsunami inundation map from simulation (Fig 2), administration border map from government, map of disaster area from drone or google map (Fig 3).

The level of threat is calculated from the data that obtained from inundation simulation. The depth of tsunami inundation is determined from this map. Then, the level of vulnerability is determined from the statistical data and government administration map, google map. The impact level could be calculated from the map of tsunami inundation and combined with administration border map from government, based those maps, the percentage area that affected by impact of tsunami disaster could be calculated. Then, using table 2,3 or 4 or 5 and 6 , the risk value for certain area is calculated, the risk priority index (RPI) are determined from table 7.

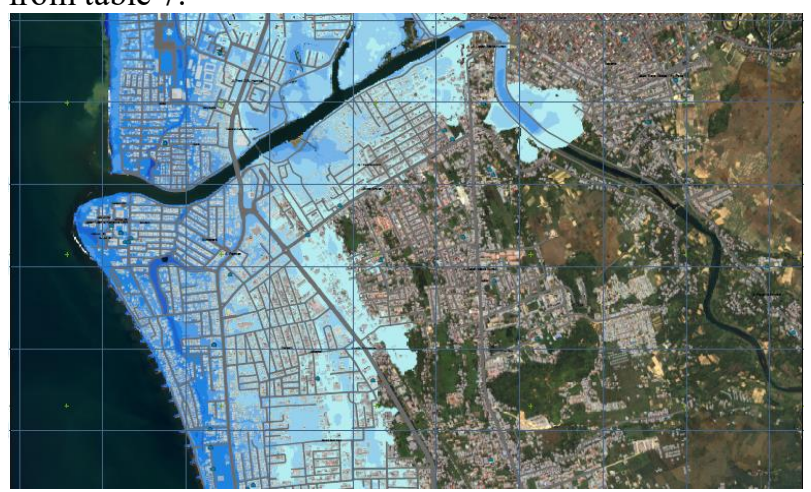

Fig 2. Inundation area.

Source: PT. Bina Lingkungan Lestari [11] 
Comparison with risk analysis method developed by FEMA and Cal OES [7], [12], this method has variable that suitable to assess the tsunami disaster.

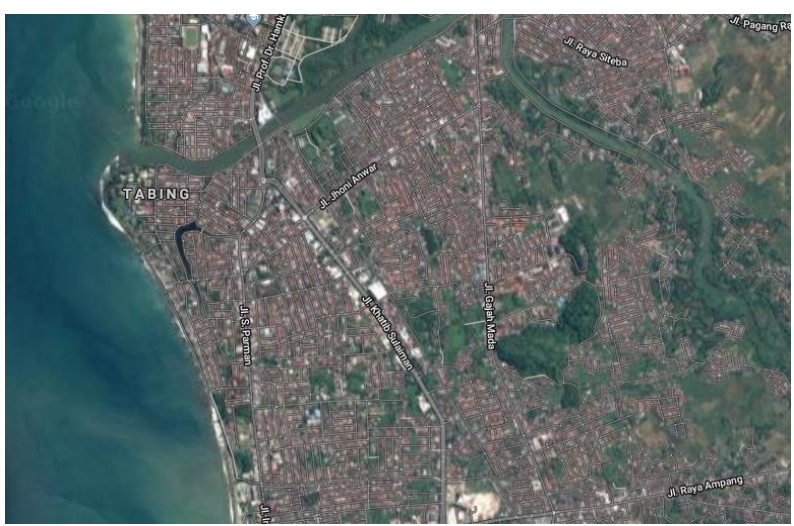

Fig 3. Land use.

Source: Google map

\section{Conclusions}

A risk analysis method has been developed based on threat, vulnerability and impact variables. Prioritisation of risk in certain area could be carried out using Risk Prioritisation Index (RPI). This method is easily implemented in practice. Further disaster prevention work could be carried out by government to prevent the impact of tsunami disaster.

Acknowledgements, the author would like to thank Andalas University that funding this research with Contract No. 8/UN.16.17/PP.PGB/LPPM/2018.

\section{References}

1. Waspada, Refleksi 13 tahun tsunami Aceh: Indonesia harus siaga bencana, 27 Desember 2017. www.waspada.co.id

2. Scheper, E, Parakrama, A, Patel, S. Impact of the Tsunami Response On Loacl and National Capabilities, (Tsunami Evaluation Coalition, London, 2006)

3. National Disaster Prevention Agency, National Disaster Prevention Plan 2015 - 2019, (2014)

4. Kementrian ESDM, 19 wilayah Indonesia rawan tsunami, masyarakat diminta waspada. (2014). www.3.esdm.go.id.

5. K. Alverbro, B. Nevhage, R. Erdeniz, Methods for Risk Analysis, 15, (2010)

6. P. Curtis, M. Carey, Risk Assessment in Pratice, 2, (2012)

7. FEMA, Risk Assessment, (2018), www.fema.gov

8. Oriental Consultant, Report: Study on counter measures of natural disaster in Indonesia (Ind), (2009)

9. United Nations Office for Disaster Risk Reduction (UNISDR), Terminology On Disaster Risk Reduction. (2017) www.unisdr.org

10. S. Sharma, R. Pratap, IJSRP, 3, 10, (2013)

11. PT. Bina Lingkungan Lestari, Peta Foto Zona Tinggi dan Jalur Evakuasi kota Padan, (2005)

12. Cal OES, State of California Threat and Hazard Identification and Risk Assessment (THIRA), (2014) 